\title{
ADME-Tox profiling of some low molecular weight water soluble chitosan derivatives
}

\author{
Adriana Isvoran*1 ${ }^{1}$, Alecu Aurel Ciorsac ${ }^{2}$ and Vasile Ostafe ${ }^{1}$ \\ ${ }^{1}$ Department of Biology-Chemistry and Advanced Environmental Research Laboratories, West University of Timișoara, \\ Timișoara, Romania \\ ${ }^{2}$ Department of Physical Education and Sport, University Politehnica Timișoara, Timișoara, Romania;
}

*Corresponding Author: E-mail: adriana.isvoran@e-uvt.ro; Tel.: +40-256-592-634; Fax: +40-256-592-620

Received: August 23, 2017; Revised: September 26, 2017; Published: September 29, 2017

\begin{abstract}
Within this study we use a few computational tools for predicting absorption, distribution, metabolism, excretion and toxicity (ADME-Tox), pharmacokinetics profiles, toxic/adverse effects, carcinogenicity, cardiotoxicity and endocrine disruption of some of low molecular weight water soluble derivatives of chitosan that are used in wound healing. Investigated compounds do not possess drug-like properties, their pharmacokinetics profiles reveal poor gastrointestinal absorption and low skin penetration. Chitosan derivatives cannot pass the blood-brain barrier and they are not able to inhibit the enzymes of the cytochrome P450 that are involved in the metabolism of xenobiotics. They do not reflect carcinogenicity and cardiotoxicity and reveal only a low probability to be endocrine disruptors. The main side effects in humans of the investigated compounds are: weight loss, acidosis, gastrointestinal toxicity, respiratory failure. This information is especially important for professional exposure and accidental contamination with these compounds.
\end{abstract}

\section{Keywords}

Pharmacokinetics; toxic/adverse effects; carcinogenicity; cardiotoxicity; endocrine disruption.

\section{Introduction}

Chitosan is a cationic polysaccharide obtained from chitin and composed by glucosamine and $\mathrm{N}$-acetyl glucosamine units, via $\beta-(1,4)$ linkages. It differs from chitin by having free amino groups. Chitosan is considered to have favourable biological properties revealing nontoxicity, mucoadhesivity, biocompatibility and biodegradability, but it is only soluble in acidic environments [1-3]. Water soluble derivatives of chitosan (WSDC) are considered to have the similar favourable properties with chitosan, but they can be dissolved in aqueous media. WSDC are interesting biomaterials with numerous applications in bioengineering and biopharmaceutical fields [4], their preparation being one of the most commonly used chemical modifications of chitosan for biomedical purposes. As pharmaceutical applications, literature data reveal that chitosan and WSDC are used as carriers for radioactive elements, carriers for drug delivery and release systems and they have antimicrobial properties [2]. Some WSDC are used to accelerate wound healing [5]. Despite literature data revealing their use in biomedical applications, chitosan and its water soluble derivatives are not approved by the US Food and Drug Administration (FDA) for drug delivery, they 
are only approved to be used for wound healing [6] and as dietary additives in Japan, Italy and Finland [7].

There are limited data in specific literature concerning the effects of chitosan and chitosan derivatives on humans, most in vivo data being obtained from studies performed on animals, usually rodents [3]. The aim of this study is to predict the ADME-Tox profiles, pharmacokinetics and toxic/adverse effects of some low molecular weight WSDC that can be used for wound healing and to compare them with those of deacetylated chitosan and partially deacetylated chitosan.

\section{Methodology}

In vitro studies revealed that chitosan and some of its water soluble derivatives have antifungal activity and may be used for wound healing purposes [5, 8-11]. According to these findings, we considered in this study 14 low molecular weight WSDC known to be useful for wound healing. In addition, for comparison purposes, we consider deacetylated chitosan and partially deacetylated chitosan, all investigated compounds being presented in Table 1 . Their simplified molecular-input line-entry system (SMILES) structures were obtained using $A C D / C h e m S k e t c h$ [12] and are used for further predictions. When the structural data files (SDF) of compounds are needed for predictions, the online translation of SMILES to SDF files is used [13].

Table 1. Molecules of WSCD considered in this study

\begin{tabular}{|c|c|}
\hline Compound common name & SMILES \\
\hline Deacetylated chitosan (2 units) & $\begin{array}{l}\text { O[C@H]2C(O[C@@H]1OC(CO)[C@@H](O)[C@H](O)C1N)[C@H](CO)OC( } \\
\text { O)C2N }\end{array}$ \\
\hline $\begin{array}{l}\text { Partially deacetylated chitosan } \\
\text { (2 units) }\end{array}$ & $\begin{array}{l}\mathrm{CC}(=\mathrm{O}) \mathrm{NC2C}(\mathrm{O})[\mathrm{C} @ \mathrm{H}](\mathrm{O}[\mathrm{C} @ @ H] 1 O C(\mathrm{CO})[\mathrm{C} @ @ H](\mathrm{O})[\mathrm{C} @ H](\mathrm{O}) \mathrm{C} 1 \mathrm{~N}) \mathrm{C}(\mathrm{C} \\
\mathrm{O}) \mathrm{C} \mathrm{C} @ \mathrm{H}] 2 \mathrm{O}\end{array}$ \\
\hline $\mathrm{N}$-carboxymethyl chitosan & O[C@@H]1OC(CO)[C@@H](O)[C@H](O)C1NCC(=O)O \\
\hline O-carboxymethyl chitosan & OC1[C@H](O)C(COCC(=O)O)O[C@@H](O)C1N \\
\hline $\mathrm{N}, \mathrm{N}$-carboxymethyl chitosan & O[C@@H]1OC(CO)[C@@H](O)[C@H](O)C1N(CC(=O)O)CC(=O)O \\
\hline $\mathrm{N}, \mathrm{O}$-carboxymethyl chitosan & O[C@@H]1OC(COCC(=O)O)[C@@H](O)C(O)C1NCC(=O)O \\
\hline $\mathrm{N}, \mathrm{N}, \mathrm{O}$-carboxymethyl chitosan & O[C@@H]1OC(COCC(=O)O)[C@@H](O)[C@H](O)C1N(CC(=O)O)CC(=O)O \\
\hline $\mathrm{N}, \mathrm{N}, \mathrm{N}$-trimethyl-chitosan & $\begin{array}{l}\mathrm{C}[\mathrm{N}+](\mathrm{C})(\mathrm{C}) \mathrm{C} 2[\mathrm{C} @ @ \mathrm{H}](\mathrm{O})[\mathrm{C} @ \mathrm{H}](\mathrm{O}) \mathrm{C}(\mathrm{CO}) \mathrm{O}[\mathrm{C} @ \mathrm{H}] 2 \mathrm{O}[\mathrm{C} @ @ \mathrm{H}] 1 \mathrm{C}(\mathrm{CO}) \mathrm{O}[\mathrm{C} \\
@ @ \mathrm{H}](\mathrm{O}) \mathrm{C}(\mathrm{N}) \mathrm{C} 1 \mathrm{O}\end{array}$ \\
\hline Chitosan-lactate & O[C@@H]1OC(CO)[C@@H](O)[C@H](O)C1NC(=O)C(C)O \\
\hline Hydroxyethyl chitosan & $\begin{array}{l}\mathrm{CC}(=\mathrm{O}) \mathrm{NC2C}(\mathrm{O})[\mathrm{C} @ \mathrm{H}](\mathrm{O}[\mathrm{C} @ @ \mathrm{H}] 1 \mathrm{OC}(\mathrm{CO})[\mathrm{C} @ @ \mathrm{H}](\mathrm{O})[\mathrm{C} @ \mathrm{H}](\mathrm{O}) \mathrm{C} 1 \mathrm{NCCO}) \\
\mathrm{C}(\mathrm{COCCO}) \mathrm{C}[\mathrm{C} @ \mathrm{H}] 2 \mathrm{O}\end{array}$ \\
\hline Hydroxypropyl chitosan & $\begin{array}{l}\mathrm{CC}(=\mathrm{O}) \mathrm{NC2C}(\mathrm{O})[\mathrm{C} @ \mathrm{H}](\mathrm{O}[\mathrm{C} @ @ \mathrm{H}] 1 \mathrm{OC}(\mathrm{CO})[\mathrm{C} @ @ \mathrm{H}](\mathrm{O})[\mathrm{C} @ \mathrm{H}](\mathrm{O}) \mathrm{C} 1 \mathrm{NCC}(\mathrm{C} \\
\mathrm{l} \text { ) C(COCC(C)O)O[C@H]2O }\end{array}$ \\
\hline Dihydroxypropyl chitosan & $\begin{array}{l}\text { CC(O)CN(CC(C)O)C2[C@@H](O)[C@H](O)C(CO)O[C@H]2O[C@@H]1C(C } \\
\text { O)O[C@@H](O)C(NC(C)=O)C1O }\end{array}$ \\
\hline $\begin{array}{l}\mathrm{N} \text {-(2-hydroxy)propyl-3- } \\
\text { trimethylammonium chitosan }\end{array}$ & $\begin{array}{l}\mathrm{C}[\mathrm{N}+](\mathrm{C})(\mathrm{C}) \mathrm{CC}(\mathrm{O}) \mathrm{CNC} 2[\mathrm{C} @ @ \mathrm{H}](\mathrm{O})[\mathrm{C} @ \mathrm{H}](\mathrm{O}) \mathrm{C}(\mathrm{CO}) \mathrm{O}[\mathrm{C} @ \mathrm{H}] 2 \mathrm{O}[\mathrm{C} @ @ \mathrm{H}] 1 \mathrm{C} \\
\mathrm{CO}) \mathrm{C} \mathrm{C} @ \mathrm{H}](\mathrm{O}) \mathrm{C}(\mathrm{NC}(\mathrm{C})=\mathrm{O}) \mathrm{C} 1 \mathrm{O}\end{array}$ \\
\hline $\begin{array}{l}\text { O-(2-hydroxy)propyl-3- } \\
\text { trimethylammonium chitosan }\end{array}$ & $\begin{array}{l}\mathrm{C}[\mathrm{N}+](\mathrm{C})(\mathrm{C}) \mathrm{CC}(\mathrm{O}) \mathrm{COCC} 2 \mathrm{O}[\mathrm{C} @ @ \mathrm{H}](\mathrm{O}) \mathrm{C}(\mathrm{NC}(\mathrm{C})=\mathrm{O}) \mathrm{C}(\mathrm{O})[\mathrm{C} @ @ \mathrm{H}] 2 \mathrm{O}[\mathrm{C} @ @ \mathrm{H} \\
] 10 \mathrm{C}(\mathrm{CO})[\mathrm{C} @ @ \mathrm{H}](\mathrm{O})[\mathrm{C} @ \mathrm{H}](\mathrm{O}) \mathrm{C} 1 \mathrm{~N}\end{array}$ \\
\hline $\mathrm{N}$-(4-carboxybutyroyl) chitosan & $\begin{array}{l}\mathrm{CC}(=\mathrm{O}) \mathrm{NC} 2 \mathrm{C}(\mathrm{O})[\mathrm{C} @ \mathrm{H}](\mathrm{O}[\mathrm{C} @ @ \mathrm{H}] 1 \mathrm{OC}(\mathrm{CO})[\mathrm{C} @ @ \mathrm{H}](\mathrm{O})[\mathrm{C} @ \mathrm{H}](\mathrm{O}) \mathrm{C} 1 \mathrm{NC}=\mathrm{O} \\
\mathrm{lCCC}) \mathrm{C}(\mathrm{CO}) \mathrm{O}[\mathrm{C} @ \mathrm{H}] 2 \mathrm{O}\end{array}$ \\
\hline N-trimethyl chitosan & $\begin{array}{l}\mathrm{CC}(=\mathrm{O}) \mathrm{NC} 2 \mathrm{C}(\mathrm{O})[\mathrm{C} @ \mathrm{H}](\mathrm{O}[\mathrm{C} @ @ \mathrm{H}] 1 \mathrm{OC}(\mathrm{CO})[\mathrm{C} @ @ \mathrm{H}](\mathrm{O})[\mathrm{C} @ \mathrm{H}](\mathrm{O}) \mathrm{C} 1[\mathrm{~N}+](\mathrm{C} \\
)(\mathrm{C}) \mathrm{C}) \mathrm{C}(\mathrm{CO}) \mathrm{O}[\mathrm{C} @ \mathrm{H}] 2 \mathrm{O}\end{array}$ \\
\hline
\end{tabular}

For the compounds considered in this study we use the following computational tools: (i) SwissADME [14] and FAFDrugs $[15,16]$ to assess their pharmacokinetics and to predict their ADME-Tox profiles, (ii) PASS online [17] for envisaging their toxic/side effects, (iii) CarcinoPred-EL [18] to predict carcinogenicity, Pred-hERG4.0 [19] to assess cardiotoxicity and ENDOCRINE DISRUPTOME [20] to evaluate their endocrine disruption potential. These tools have been selected among the numerous computational utilities destined 
to predict the ADME-Tox profile and pharmacokinetics because of their continuous update, accessibility by free-login on the websites and of their robustness, accompanied by easy inputs and interpretations.

SwissADME is a free available on-line computational tool allowing online computation of the physicochemical properties of one or multiple molecules and prediction of pharmacokinetics, drug-likeness and medicinal chemistry friendliness [14]. It computes for every molecule: the chemical structure, physicochemical properties (such as molecular weight, topological polar surface area considering phosphorous and sulphur as polar atoms, molar refractivity, etc), lipophilicity, water solubility, bioavailability radar, pharmacokinetics, the skin permeability coefficient, drug-likeness and medicinal chemistry. Lipophilicity is expressed by the partition coefficient between n-octanol and water $\left(\log P_{\mathrm{o} / \mathrm{w}}\right)$ which is computed under SwissADME tool by implementing five different methods based on distinct approaches and displaying both the values obtained using these methods and a consensus $\log P_{\mathrm{o} / \mathrm{w}}$ as the arithmetic mean of the predicted values. Concerning the skin permeability coefficient, it is expressed in log units and a more negative log $K_{\mathrm{p}}$ value corresponds to a less skin permeant molecule. As an example, the skin permeability coefficient of diclofenac (that is known to have a good skin permeability) is predicted as $\log K_{\mathrm{p}}=-4.96 \mathrm{~cm} / \mathrm{s}$ and those of ouabain (that is not able to penetrate the skin) is predicted as $\log K_{\mathrm{p}}=-10.94 \mathrm{~cm} / \mathrm{s}$ [21]. When displaying the bioavailability radar, six physicochemical properties are taken into account: size, polarity, lipophilicity, solubility, flexibility and saturation. Concerning the pharmacokinetics, drug-likeness and medicinal chemistry predictions, the SwissADME classifiers reveal a similar accuracy of prediction as the other tools, demonstrating strong correlation between predicted and experimental values for molecules belonging to the training sets [14].

FADrugs is another free available online computational toll allowing analysing or filtering of molecules with eight predefined physicochemical filters based on several simple ADME-Tox rules [15, 16]. This tool allows the following procedures: (i) a data curation stage by desalting molecules and removing large molecules and compounds containing some types of inorganic atoms or duplicates, (ii) the computation of several physicochemical properties of molecules and their filtering considering several ADME-Tox rules, (iii) the detection of potential toxic groups, aggregators and PAINS [15, 16]. FAFDrugs tool has been validated by using a list of 40 documented toxicophores and a list of 778 annotated oral drugs used in 19 therapeutic areas. An alert was detected in 36 among the 40 toxicophores with $100 \%$ efficacy with regard to the nature of the alerts and among the 778 drugs, $81 \%$ satisfied the rules $[15,16]$.

Prediction of Activity Spectra of Substances (PASS) is a computational tool allowing prediction of biological activity and/or toxic and side effects of a chemical compound starting from its structural formula, the mean accuracy of prediction being about $90 \%$ [17]. PASS algorithm estimates the probability that the investigated compound belongs to a particular class of active compounds $(\mathrm{Pa})$ or inactive compounds $(\mathrm{Pi})$. The value of $P$ a reveals the similarity of the molecule under investigation with the structures of those molecules within the training set which are the most typical in a subset of "actives". Correspondingly, $P \mathrm{i}$ reflects the similarity of the investigated compound with the molecules within the training set that belongs to the subset of "inactive". The two probabilities values $(P a$ and $P$ i) vary from 0 to 1 and are independent. Only those activities with $\mathrm{Pa}>\mathrm{Pi}$ are considered as promising for a particular compound and a good accuracy of prediction is obtained when $\mathrm{Pa}>0.7$ [17].

CarcinoPred-EL is a free prediction online server based on twelve different molecular fingerprints and ensemble machine learning methods allowing identification of the structural features related to carcinogenic effects of organic compounds [18]. It uses 1003 compounds with known carcinogenicity against rats (494 carcinogens and 509 non-carcinogens) that are found in the Carcinogenic Potency 
Database [22] as the training dataset to develop models for predicting the carcinogenicity and an external validation dataset of 40 compounds ( 23 carcinogens and 17 non-carcinogens) from the ISSCAN database [23] that do not duplicate the training dataset and the accuracy of prediction is about $70 \%$.

Pred-hERG is a free accessible web tool that builds predictive QSAR (Quantitative Structure Activity Relationship) models of hERG K+ channel blockage. The predictions are built using the largest free available dataset of structurally diverse compound with 16932 associated bioactivity records for the hERG liability that are contained in the ChEMBL database [24] with an accuracy up to $89 \%$ [19].

ENDOCRINE DISRUPTOME is a free web service able to assess the endocrine disruption potential of a chemical compound by using the molecular docking method based on AutoDock Vina algorithm [25]. Investigated compound is docked to 18 crystallographic structures available in the Protein Data Bank [26] for 14 distinct human nuclear receptors: androgen receptor; estrogen receptors $\alpha$ and $\beta$; glucocorticoid receptor; liver $X$ receptors $\alpha$ and $\beta$; mineralocorticoid receptor; peroxisome proliferator activated receptors $\alpha, \beta / \delta$, and $\gamma$; progesterone receptor; retinoid $X$ receptor $\alpha$; thyroid receptors $\alpha$ and $\beta$ [20]. The service was validated on small drug-like molecules with molecular weight under 600 . Results furnished by ENDOCRINE DISRUPTOME are dived in 4 classes based on three thresholds of sensitivity (SE) that are set per structure and are used to obtain the docking scores: one class with high probability of binding (SE < $0.25)$, two classes with medium probability of binding $(0.25<\mathrm{SE}<0.50$ and $0.50<\mathrm{SE}<0.75)$ and one class with low probability of binding. (SE >0.75) [20].

\section{Results and Discussion}

ADME-Tox profiles generated using the SwissADME tool and the drug-like and respiratory filters of implemented under FAFDrugs tool reflect that compounds considered in this study do not possess druglike characteristics, some of their physicochemical properties (partition coefficient $-\log P$, number of hydrogen bonds donors - HBD, total number of hydrogen bonds donors and acceptors - HBD_HBA, topological polar surface area - tPSA) being outside the permitted limits for drugs (Figures 1 and 2), and such as violating many rules (Table 2 ).

Figures $1 \mathrm{a}$ and $1 \mathrm{~b}$ illustrate the use of FAFDrugs tool to obtain the positioning of the physicochemical properties of $\mathrm{N}$-carboxymethyl chitosan (CMC) (a) and N,N,N-trimethyl chitosan (TMC) (b) respectively by compassion to the drug-like properties. Figures $2 a$ and $2 b$ show the positioning of the physicochemical properties of CMC (a) and TMC (b) respectively when the respiratory filter is applied under FAFDrugs tool.

(a)

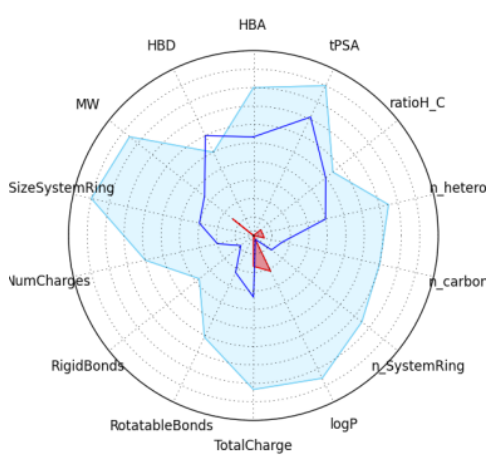

(b)

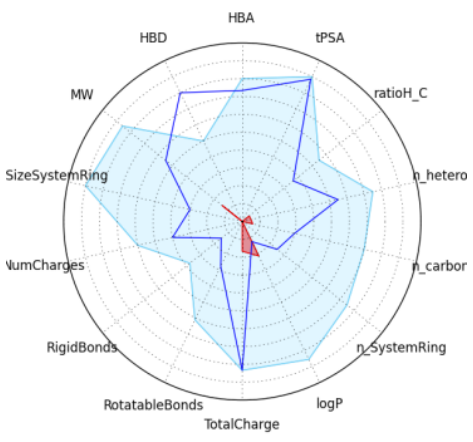

Figure 1. Radar pictures of the positioning of the physicochemical properties of investigated compounds (dark blue line) by comparison to the properties corresponding to drug-like molecules (light blue region) (a) $\mathrm{N}$ carboxymethyl chitosan, (b) N,N,N-trimethyl-chitosan. 
(a)

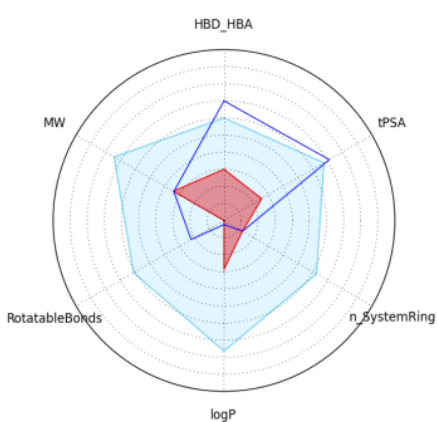

(b)

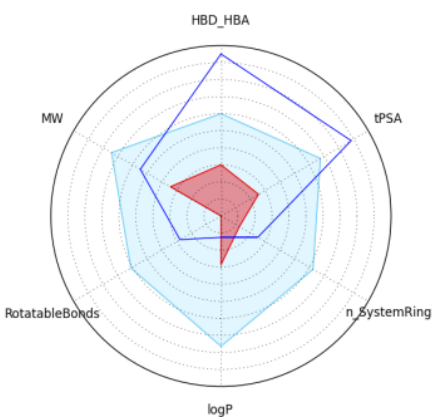

Figure 2. Radar pictures of the positioning of the physicochemical properties of investigated compounds (dark blue line) by comparison to the properties corresponding to molecules that can be used as respiratory drugs (light blue region) (a) N-carboxymethyl chitosan, (b) N,N,N-trimethyl-chitosan.

Table 2. Druglikeness of the WSCD considered in this study

\begin{tabular}{|c|c|c|c|c|c|c|c|}
\hline \multirow[t]{2}{*}{ Compound } & \multicolumn{5}{|c|}{ Number of violations } & \multirow{2}{*}{$\begin{array}{l}\text { Lilly } \\
\text { MedChem } \\
\text { rules }\end{array}$} & \multirow{2}{*}{$\begin{array}{c}\text { Bioavailability } \\
\text { score }\end{array}$} \\
\hline & Lipinski & $\begin{array}{c}\text { Ghose } \\
\text { (Bayer) }\end{array}$ & Veber & Egan & Muege & & \\
\hline $\begin{array}{l}\text { Deacetylated chitosan } \\
\text { (2 units) }\end{array}$ & 2 & 1 & 1 & 1 & 4 & Pass & 0.17 \\
\hline $\begin{array}{l}\text { Partially deacetylated } \\
\text { chitosan ( } 2 \text { units) }\end{array}$ & 2 & 3 & 1 & 1 & 4 & Pass & 0.17 \\
\hline N-carboxymethyl chitosan & 1 & 1 & 0 & 1 & 2 & Pass & 0.55 \\
\hline O-carboxymethyl chitosan & 0 & 1 & 1 & 1 & 1 & Pass & 0.55 \\
\hline $\begin{array}{l}\mathrm{N}, \mathrm{N} \text {-carboxymethyl } \\
\text { chitosan }\end{array}$ & 1 & 1 & 1 & 1 & 3 & Pass & 0.11 \\
\hline $\begin{array}{l}\mathrm{N}, \mathrm{O} \text {-carboxymethyl } \\
\text { chitosan }\end{array}$ & 1 & 1 & 1 & 1 & 3 & Pass & 0.11 \\
\hline $\begin{array}{l}\mathrm{N}, \mathrm{N}, \mathrm{O} \text {-carboxymethyl } \\
\text { chitosan }\end{array}$ & 2 & 1 & 1 & 1 & 4 & Do not pass & 0.11 \\
\hline $\mathrm{N}, \mathrm{N}, \mathrm{N}$-trimethyl-chitosan & 1 & 1 & 1 & 1 & 3 & Pass & 0.55 \\
\hline Chitosan-lactate & 1 & 1 & 0 & 1 & 1 & Pass & 0.55 \\
\hline Hydroxyethyl chitosan & 2 & 1 & 2 & 1 & 4 & Pass & 0.17 \\
\hline Hydroxypropyl chitosan & 2 & 3 & 2 & 1 & 4 & Pass & 0.17 \\
\hline Dihydroxypropyl chitosan & 2 & 3 & 2 & 1 & 4 & Pass & 0.17 \\
\hline $\begin{array}{l}\mathrm{N} \text {-(2-hydroxy)propyl-3- } \\
\text { trimethylammonium } \\
\text { chitosan }\end{array}$ & 2 & 3 & 2 & 1 & 4 & Do not pass & 0.17 \\
\hline $\begin{array}{l}\text { O-(2-hydroxy)propyl-3- } \\
\text { trimethylammonium } \\
\text { chitosan }\end{array}$ & 2 & 3 & 2 & 1 & 4 & Do not pass & 0.17 \\
\hline $\begin{array}{l}\mathrm{N} \text {-(4-carboxybutyroyl) } \\
\text { chitosan }\end{array}$ & 2 & 1 & 1 & 1 & 4 & Pass & 0.17 \\
\hline $\mathrm{N}$-trimethyl chitosan & 2 & 1 & 1 & 1 & 3 & Do not pass & 0.17 \\
\hline
\end{tabular}

With the exception of $\mathrm{N}$-carboxymethyl chitosan, O-carboxymethyl chitosan and N,N,N-trimethylchitosan, chitosan and the other WSDC reveal a low oral bioavailability. From the point of view of safety, FAFDrugs tool exposes that all these compounds reflect no toxicity, but some of them are able to induce phospholipidosis. It is not an unexpected result, as it is generally recognized that phospholipidosis is a response to cells exposed to cationic amphiphilic substances [27].

Pharmacokinetics of investigated compounds has been obtained using SwissADME tool and is revealed in Table 3. The results presented in Table 3 indicate that all investigated compounds present a low gastrointestinal absorption, low skin permeation and they are not able to inhibit any of the cytochromes P450 (CYP) involved in metabolism of xenobiotics. These compounds are predicted to be substrates for 
P-gp, another pharmacokinetics-relevant protein, emphasizing their active efflux through biological membranes.

Table 3. Pharmacokinetics of water soluble chitosan derivatives: GI- gastrointestinal absorption, BBB - blood brain barrier penetration, P-gp - substrate of the P-gp protein, CYP- cytochrome P450, Log Kp-skin permeation coefficient

\begin{tabular}{|c|c|c|c|c|c|c|c|c|c|}
\hline Compound & GI & BBB & P-gp & CYP1A2 & CYP2D6 & CYP2C9 & CYP2C19 & $\begin{array}{c}\text { CYP3A } \\
4\end{array}$ & $\begin{array}{l}\log K_{p} \\
(\mathrm{~cm} / \mathrm{s})\end{array}$ \\
\hline Deacetylated chitosan & low & no & yes & no & no & no & no & no & -12.10 \\
\hline $\begin{array}{l}\text { Partially deacetylated } \\
\text { chitosan }\end{array}$ & low & no & yes & no & no & no & no & no & -12.18 \\
\hline $\begin{array}{l}\text { O-carboxymethyl } \\
\text { chitosan }\end{array}$ & low & no & yes & no & no & no & no & no & -11.69 \\
\hline $\begin{array}{l}\mathrm{N}, \mathrm{N} \text {-carboxymethyl } \\
\text { chitosan }\end{array}$ & low & no & yes & no & no & no & no & no & -12.08 \\
\hline $\begin{array}{l}\mathrm{N}, \mathrm{O} \text {-carboxymethyl } \\
\text { chitosan }\end{array}$ & low & no & yes & no & no & no & no & no & -11.96 \\
\hline $\begin{array}{l}\mathrm{N}, \mathrm{N}, \mathrm{O} \text {-carboxymethyl } \\
\text { chitosan }\end{array}$ & low & no & yes & no & no & no & no & no & -12.27 \\
\hline $\begin{array}{l}\mathrm{N} \text {-carboxymethyl } \\
\text { chitosan }\end{array}$ & low & no & yes & no & no & no & no & no & -11.77 \\
\hline $\begin{array}{l}\mathrm{N}, \mathrm{N}, \mathrm{N} \text {-trimethyl- } \\
\text { chitosan }\end{array}$ & low & no & yes & no & no & no & no & no & -11.66 \\
\hline Chitosan-lactate & low & no & yes & no & no & no & no & no & -12.27 \\
\hline Hydroxyethyl chitosan & low & no & yes & no & no & no & no & no & -12.94 \\
\hline $\begin{array}{l}\text { Hydroxypropyl } \\
\text { chitosan }\end{array}$ & low & no & yes & no & no & no & no & no & -12.50 \\
\hline $\begin{array}{l}\text { Dihydroxypropyl } \\
\text { chitosan }\end{array}$ & low & no & yes & no & no & no & no & no & -12.55 \\
\hline $\begin{array}{l}\mathrm{N} \text {-(2-hydroxy)propyl-3- } \\
\text { trimethylammonium } \\
\text { chitosan }\end{array}$ & low & no & yes & no & no & no & no & no & -12.92 \\
\hline $\begin{array}{l}\text { O-(2-hydroxy)propyl-3- } \\
\text { trimethylammonium } \\
\text { chitosan }\end{array}$ & low & no & yes & no & no & no & no & no & -12.92 \\
\hline $\begin{array}{l}\mathrm{N}-(4-\text { carboxybutyroyl) } \\
\text { chitosan }\end{array}$ & low & no & yes & no & no & no & no & no & -11.94 \\
\hline $\mathrm{N}$-trimethyl chitosan & low & no & yes & no & no & no & no & no & -11.74 \\
\hline
\end{tabular}

Results concerning side/toxic effects of compounds considered in this study were obtained using PASS online and are presented in Table 4. When considering the predictions made by PASS online tool, we only took into account those results with the probability of a compound to be active higher than 0.9. These results illustrate that WSDC reflect fewer and less important side/toxic effects than deacetylated and partially deacetylated chitosan.

CarcinoPred-EL tool reflects that all considered compounds belong to the non-carcinogen class of substances. Pred-hERG results also indicate that the investigated compounds are non-blockers for the hERG K ${ }^{+}$channels and do not reflect cardiotoxicity.

ENDOCRINE DISRUPTOME tool emphasizes that WSCD considered in this study have a low inhibitory potential of endocrine system-specific proteins. 
Table 4. Toxic effects of compounds considered in this study

\begin{tabular}{|c|c|}
\hline Compound & Toxic effects \\
\hline $\begin{array}{l}\text { Deacetylated chitosan - } 2 \\
\text { units }\end{array}$ & $\begin{array}{l}\text { weight loss, acidosis, nausea, gastrointestinal toxicity, hematotoxicy, } \\
\text { respiratory failure, reproductive dysfunction, neurotoxicity }\end{array}$ \\
\hline $\begin{array}{l}\text { Partially deacetylated } \\
\text { chitosan - } 2 \text { units }\end{array}$ & $\begin{array}{l}\text { weight loss, acidosis, nausea, gastrointestinal toxicity, nephrotoxicity, } \\
\text { hematotoxicity, thrombocytopenia, pain, respiratory failure, cyanosis, } \\
\text { necrosis, reproductive dysfunction, neurotoxicity }\end{array}$ \\
\hline $\begin{array}{l}\text { O-carboxymethyl chitosan } \\
\text { (1 unit) }\end{array}$ & $P a<0.9$ \\
\hline $\begin{array}{l}\mathrm{N}, \mathrm{N} \text {-carboxymethyl } \\
\text { chitosan (1 unit) }\end{array}$ & $P a<0.9$ \\
\hline $\begin{array}{l}\mathrm{N}, \mathrm{O} \text {-carboxymethyl } \\
\text { chitosan (1 unit) }\end{array}$ & $P a<0.9$ \\
\hline $\begin{array}{l}\mathrm{N}, \mathrm{N}, \mathrm{O} \text {-carboxymethyl } \\
\text { chitosan }\end{array}$ & $P a<0.9$ \\
\hline N-carboxymethyl chitosan & weight loss, acidosis, respiratory failure, inflammation \\
\hline $\mathrm{N}, \mathrm{N}, \mathrm{N}$-trimethyl-chitosan & weight loss, acidosis, respiratory failure, gastrointestinal toxicity \\
\hline Chitosan-lactate & $\begin{array}{l}\text { acidosis, weight loss, nausea, hematotoxicity, gastrointestinal toxicity, } \\
\text { hyperglycemic, respiratory failure, cyanoses, leukopenia }\end{array}$ \\
\hline Hydroxyethyl chitosan & $\begin{array}{l}\text { hematotoxicity, nephrotoxicity, respiratory failure, acidosis, } \\
\text { thrombocytopenia, allergic dermatitis, gastrointestinal toxicity, nausea, } \\
\text { asthma, necrosis, cyanosis, leukopenia, neurotoxicity }\end{array}$ \\
\hline Hydroxypropyl chitosan & $\begin{array}{l}\text { hematotoxicity, acidosis, nausea, gastrointestinal toxicity, dermatitis, } \\
\text { nephrotoxicity }\end{array}$ \\
\hline Dihydroxypropyl chitosan & acidosis, nausea, gastrointestinal toxicity, respiratory failure \\
\hline $\begin{array}{l}\mathrm{N}-(2-\text { hydroxy)propyl-3- } \\
\text { trimethylammonium } \\
\text { chitosan }\end{array}$ & N/A \\
\hline $\begin{array}{l}\text { O-(2-hydroxy)propyl-3- } \\
\text { trimethylammonium } \\
\text { chitosan }\end{array}$ & $\mathrm{N} / \mathrm{A}$ \\
\hline $\begin{array}{l}\mathrm{N}-(4-\text { carboxybutyroyl) } \\
\text { chitosan }\end{array}$ & $\begin{array}{l}\text { weight loss, acidosis, hematotoxicity, nausea, gastrointestinal toxicity, } \\
\text { neurotoxicity, respiratory failure }\end{array}$ \\
\hline N-trimethyl chitosan & N/A \\
\hline
\end{tabular}

\section{Conclusions}

As there are limited experimental in vivo studies concerning the pharmacological and toxicological effects of chitosan and its WSD on humans, computational predictions of their pharmacokinetics and adverse effects may provide useful information. Chitosan and its derivatives considered in this study reflect low skin permeability and low inhibitory potential for the proteins specific to the endocrine system. They are not able to penetrate the blood brain barrier and to affect the central nervous system and they are not predicted to have an inhibitory potential for the enzymes of the cytochrome P450 involved in drugs and other xenobiotics metabolism. They are predicted to be substrates for the P-gp protein and it illustrate that their systemic exposure could be reduced. By comparison to chitosan and deacetylated chitosan, some WSDC show good oral bioavailability. Furthermore, the investigated compounds do not reveal carcinogenic potential and cardiac toxicity, but they are predicted to induce phospholipidosis and to have some adverse effects: weight loss, acidosis, gastrointestinal toxicity, respiratory failure. Some of the predicted pharmacological and toxicological profiles of the considered WSDC are in good agreement with a few experimental studies revealing that WSDC have no or low cytotoxicity [28, 29], no genotoxicity [28], have fat- and cholesterol-binding capacities producing weight loss [30]. Their side effects increase with the molecular weight and degree of deacetylation [31]. This agreement strengthens the outcomes of this study and illustrates the utility of the methods. 
To the best of our knowledge, this is a first study dealing with the ADME-Tox properties of chitosan and some of its water soluble derivatives that are used for wound healing. Chitosan and its water-soluble derivatives are approved by the US Food and Drug Administration only to be used for wound healing. As they reflect low skin penetration, people being treated with these compounds reveal only a low degree of exposure. The obtained information is important especially for people manufacturing and handling these compounds being occupationally exposed to these chemicals.

Acknowledgements: This work is supported by GRANT PNIII-P3-284, ChitoWound - Biotechnological tools implementation for new wound healing applications of byproducts from the crustacean seafood processing industry.

\section{References}

[1] R. Riva, H. Ragelle, A. des Rieux, N. Duhem, C. Jérôme, V. Préat, Advanced Polymers Science 244 (2011) 19-44; https://link.springer.com/chapter/10.1007\%2F12 2011137.

[2] R.C. Cheung, T.B. Ng, J.H. Wong, W.Y. Chan, Marine Drugs 13 (2015) 5156-5186; http://www.mdpi.com/1660-3397/13/8/5156.

[3] M.D. Gades, J.S. Stern, Obesity Research $11 \quad$ (2003) 683-688; http://onlinelibrary.wiley.com/doi/10.1038/oby.2003.97/full.

[4] Q.-X. Wu, D.-Q. Lin, S.-J.Yao, Marine Drugs 12 (2014) 6236-6253; http://www.mdpi.com/1660-3397/12/12/6236.

[5] V. Patrulea, V. Ostafe, G. Borchard, O. Jordan, European Journal of Pharmaceutics and Biopharmaceutics 97 (2015) 417-426;

http://linkinghub.elsevier.com/retrieve/pii/S0144861716300091.

[6] I.Wedmore, J.G. McManus, A.E. Pusateri, J.B. Holcomb, Journal of Trauma 60 (2006) 655-658; https://www.ncbi.nlm.nih.gov/pubmed/16531872.

[7] L. Illum, Pharmaceutical Research 15 (1998) 1326-1331; https://www.ncbi.nlm.nih.gov/pubmed/9755881.

[8] F. Seyfarth, S. Schliemann, P. Elsner, U.C. Hipler, International Journal of Pharmaceutics 353 (2008) 139-148; http://europepmc.org/abstract/med/18164151.

[9] K. Azuma, R. Izumi, T. Osaki, S. Ifuku, M. Morimoto, H. Saimoto, S.o Minami, Y. Okamoto, Journal of Functional Biomaterials 6 (2015) 104-142; https://www.ncbi.nlm.nih.gov/pmc/articles/PMC4384104/.

[10] M. Sobol, A. Bartkowiak, B. de Haan, P. de Vos, Journal of Biomedical Materials Research Part A 101A (2013) 1907-1914; http://onlinelibrary.wiley.com/doi/10.1002/jbm.a.34500/abstract.

[11] J. Macossay, LSU Historical Dissertations and Theses (1995) 6119; http://digitalcommons.Isu.edu/gradschool disstheses/6119.

[12] ACD ChemSketch 12.00 and chemicalize from chemaxon; https://chemicalize.com; accessed 01.08.2017.

[13] Online SMILES Translator and Structure File Generator; https://cactus.nci.nih.gov/translate/; accessed 06.08.2017 and 24.09.2017.

[14] A. Daina, O. Michielin, V. Zoete, Scientific Reports 7 (2017) 42717; https://www.nature.com/articles/srep42717?WT.feed name=subjects physical-sciences. 
[15] D. Lagorce, O. Sperandio, J.B. Baell, M.A. Miteva, B.O. Villoutreix, Nucleic Acids Research 43 (2015) W200-207;

https://www.ncbi.nlm.nih.gov/pmc/articles/PMC4489254/.

[16] D. Lagorce, L. Bouslama, J. Becot, M.A. Miteva, B.O. Villoutreix, Bioinformatics (2017) accepted manuscript;

https://doi.org/10.1093/bioinformatics/btx491.

[17] A.V. Stepanchikova, A.A. Lagunin, D.A. Filimonov, V.V. Poroikov, Current Medicinal Chemistry 10 (2003) 225-233; https://pdfs.semanticscholar.org/33af/3c27932acc01595715a322d2795ac45ae2cd.pdf.

[18] L. Zhang, H. Ai, W. Chen, Z.Yin, H. Hu, J. Zhu, J. Zhao, Q. Zhao, H. Liu, Scientific Reports 7 (2017) 2118;

https://www.nature.com/articles/s41598-017-02365-0.

[19] R.C. Braga; V.M. Alves, M.F.B. Silva; E. Muratov, D. Fourches, L.M. Liao, A. Tropsha, C.H. Andrade, Molecular Informatics 34 (2015) 698-701;

http://onlinelibrary.wiley.com/doi/10.1002/minf.201500040/suppinfo.

[20] K. Olšek, J. Mavri, M Sollner Dolenc, S. Gobec, S. Turk, Journal of Chemical Information and Modeling 54 (2014) 1254-1267; http://pubs.acs.org/doi/abs/10.1021/ci400649p.

[21] R.O. Potts, R.H. Guy, Pharmaceutical Research 5 (1992) 663-669.

[22] L. S. Gold, T. H. Slone, N. B. Manley, G. B. Garfinkel, E. S. Hudes, L. Rohrbach, B. N. Ames, Environmental Health Perspectives 96 (1991) 11-15; http://pubmedcentralcanada.ca/pmcc/articles/PMC1568255/pdf/envhper00416-0018.pdf.

[23] R. Benigni, C. Bossa, A. M. Richard, C. Yang, Annali dell'Istituto Superiore Di Sanita 44 (2008) 48-56; http://www.iss.it/publ/anna/2008/1/44148.pdf.

[24] A.P. Bento, A. Gaulton, A. Hersey, L.J. Bellis, J. Chambers, M. Davies, F.A. Krüger, Y. Light, L. Mak, S. McGlinchey, M. Nowotka, G. Papadatos, R. Santos, J.P. Overington, Nucleic Acids Research 42 (2014) 1083-1090; https://academic.oup.com/nar/article-lookup/doi/10.1093/nar/gkt1031.

[25] O. Trott, A. J. Olson, Journal of Computational Chemistry 31 (2010) 455-461; https://www.ncbi.nlm.nih.gov/pmc/articles/PMC3041641/.

[26] H.M. Berman, J. Westbrook, Z. Feng, G. Gilliland, T.N. Bhat, H. Weissig, I.N. Shindyalov, P.E. Bourne, Nucleic Acids Research 28 (2000) 235-242;

https://www.ncbi.nlm.nih.gov/pmc/articles/PMC102472/.

[27] J. A. Shayman, A. Abe, Biochimica and Biophysica Acta 1831 (2013) 602-611; https://www.ncbi.nlm.nih.gov/pmc/articles/PMC3528828/.

[28] E.M. Costa, S. Silva, M.R. Costa, M. Pereira, D.A. Campos, J. Odila, A.R. Madureira, A. CardelleCobas, F.K. Tavaria, , A.S. Rodrigues, Carbohydrate Polymers 111 (2014) 385-392;

http://www.sciencedirect.com/science/article/pii/S0144861714004032?via\%3Dihub.

[29] C.Y. Chen, Y.C. Chung, Journal of Applied Oral Science 20 (2012) 620-627; https://www.ncbi.nlm.nih.gov/pmc/articles/PMC3881855/.

[30] Q. Jin, H. Yu, X. Wang, K. Li, P. Li, PeerJ 5 (2017) e3279; https://dx.doi.org/10.7717/peerj.3279.

[31] T. Kean, M. Thanou, Advanced Drug Delivery Reviews, 62 (2010) 3-11; http://www.sciencedirect.com/science/article/pii/S0169409X0900283X?via\%3Dihub. 